\title{
Evaluating the Effects of Removing Fines from Particleboards Manufactured from Amazonian Wood Residue
}

\author{
Paula Gabriella Surdi ${ }^{1}$, Geraldo Bortoletto Junior ${ }^{1}$, Vinicius Resende de Castro ${ }^{2}$ \\ ${ }^{1}$ Escola Superior de Agricultura "Luiz de Queiroz" - ESALQ, Universidade de São Paulo - USP, Piracicaba/SP, Brasil \\ ${ }^{2}$ Universidade Federal de Viçosa - UFV, Viçosa/MG, Brasil
}

\begin{abstract}
The aim of this research was to evaluate the effects of removing fines on the physical and mechanical properties of high-density particleboard produced by mechanical processing of Caryocar villosum (pequiá), Tachigali myrmecophyla (tachi-preto) and Hymenolobium excelsum (angelim-da-mata) Amazonian woods. The panels were produced with nominal density of $850 \mathrm{~kg} \cdot \mathrm{m}^{-3}$, thickness of $15.7 \mathrm{~mm}$ and phenol formaldehyde adhesive. The experimental design was arranged in a factorial design, with the assessment of the effects of three species (pequiá, tachi-preto and angelim-da-mata) and two particle classifications (with and without fines). Their performance was evaluated with respect to their physical (apparent density, moisture content, water absorption and thickness swelling) and mechanical (static bending - modulus of elasticity and modulus of rupture and internal bond) properties, realized according to ABNT NBR 14810-3. The removal of fines in the production of panels generated a tendency towards increased MoR, MoE and internal bond values and contributed to reductions in AAw2h, AAw24h and ST2h.
\end{abstract}

Keywords: tropical wood, wood panels, particles classification. 


\section{INTRODUCTION}

Particleboards are produced by mechanically reducing raw wood into wood particles, incorporating an adhesive and consolidating a particle-mat using temperature and pressure (Maloney, 1993; Iwakiri, 2005; Stark et al., 2010).

Physical and mechanical properties of wood panels depend on parameters that may affect their strength and dimensional stability, and consequently significantly influence their final quality. Particle geometry, including shape and size, is one of the main parameters that affects particleboard properties (Moslemi, 1974; Frybort et al., 2008). According to Juliana et al. (2012), such a parameter can substantially affect the quality of adhesion between the particles, consequently influencing the strength and rigidity of the panels.

Slenderness ratio is the ratio between the length and thickness of the particles and is an important parameter because the contact area between the particles in the panel and the relative adhesive consumption depends on it (Iwakiri, 1989). By changing the geometry or particle size, there is also a need to determine the best proportion of adhesive to use, among other process variables (Peixoto \& Brito, 2000).

According to Moslemi (1974), longer, thinner particles produce plates with greater resistance to static bending and dimensional stability, while shorter, thicker particles produce plates with greater internal bonding and less dimensional stability. Moreover, according to the same author, particles with smaller dimensions require higher relative adhesive consumption, considering the greater specific surface area of the particles to be covered. By applying the same amount of adhesive, a particleboard produced with larger particles will have greater internal bonding due to its smaller specific surface area, and consequently, greater availability of adhesive per unit area (Maloney, 1993). Therefore, the dimensional elements of the particles must be defined according to the particleboard type and its required quality.

Several studies have shown the influence of the particle's geometry on the physical-mechanical properties of particleboards over the years, among which we can highlight those by Rackwitz (1963), Ong (1981), Vital et al. (1992), Brito (1995), Juliana et al. (2012),
Rofii et al. (2013), Torrell et al. (2013) and Lias et al. (2014).

In this context, the present study sought to evaluate the effect of removing fines on the physical and mechanical properties of high-density particleboards produced from residue generated by the mechanical processing of the Amazonian woods: Caryocar villosum (Aubl.) Pers. (known in Brazil as pequiá), Tachigali myrmecophyla Ducke (known in Brazil as tachi-preto) and Hymenolobium excelsum Ducke (known in Brazil as angelim-da-mata).

\section{MATERIAL AND METHODS}

\subsection{Collection and preparation of the material}

The three tree species selected to realize the present study were Caryocar villosum (Aubl.) Pers., Tachigali myrmecophyla Ducke and Hymenolobium excelsum Ducke, from the Unidade de Produção Anual - 06, located in an area of sustainable forest management, certified by the FSC and belonging to the Orsa Florestal Group located in Vale do Jari, district of Monte Dourado, municipality of Almeirim - PA, Brazil.

After the trees were cut, a $2.5 \mathrm{~m}$ log was removed from the basal part of the shaft. While still in the forest, each log was sawn into $17 \mathrm{~cm} \times 17 \mathrm{~cm} \times 250 \mathrm{~cm}$ (width, thickness and length, respectively) wood blocks. The resulting blocks were collected and transported to the Department of Forest Sciences - LCF of the Luiz de Queiroz College of Agriculture in Piracicaba - SP, where they were processed.

Considering the availability of material generated in the form of wood residues from sawing operations of blocks into lumber, as well as the waste generated from producing specimens for physico-mechanical testing, we chose to use the material generated by the mechanical wood processing.

Initially, wood residues were transformed into chips by a forest chipper powered by a tractor's power outlet. Subsequently, the wood particles were produced by processing the chips in a Willey knife mill using a $4 \mathrm{~mm}$ sieve opening. The particles were then dried in a laboratory forced-air circulation oven at a temperature of $90{ }^{\circ} \mathrm{C}$. Drying was concluded when the particles reached moisture content between 3 and 5\%. 
The granulometric classification of the particles was carried out using a vibrating machine equipped with sieves of $50 \times 50 \times 10 \mathrm{~cm}$ dimension, using $4.00 \mathrm{~mm}$, $2.00 \mathrm{~mm}, 0.85 \mathrm{~mm}, 0.50 \mathrm{~mm}$ mesh and collector. The particles that passed through the $0.50 \mathrm{~mm}$ sieve were classified as fines.

\subsection{Experimental design}

Six (6) treatments were adopted to manufacture the particleboards, as described in Table 1. Three (3) particleboards with a nominal specific mass of $850 \mathrm{~kg} \cdot \mathrm{m}^{-3}$ and nominal thickness of $15.7 \mathrm{~mm}$ were produced for each of the treatments.

The study followed a completely randomized experimental design with a $3 \times 2$ factorial design for the treatments, in which the factors were the wood species (Caryocar villosum (Aubl.) Pers., Tachigali myrmecophyla Ducke and Hymenolobium excelsum Ducke) and the particle classifications (including the fine particles retained in the vibratory machine collector and disregarding the fines - using the particles classified between the $2.00 \mathrm{~mm}, 0.85 \mathrm{~mm}$ and $0.5 \mathrm{~mm}$ meshes), respectively.

\subsection{Particleboard manufacturing}

The adhesive applied to the particles was liquid phenol-formaldehyde, with a solids content of $52.32 \%$, gel time at $121^{\circ} \mathrm{C}$ of 8.19 minutes, and viscosity of $640 \mathrm{cP}$ at $25^{\circ} \mathrm{C}$, with the amount of $8 \%$ resin solids calculated based on the dry mass of the particles. Liquid paraffin was also applied to the particles for all treatments in the amount of $1 \%$ solids, calculated on the same basis as the adhesive. Application of the adhesive and the paraffin emulsion were performed separately in this order on a rotary drum type gluer set to rotate at $12 \mathrm{RPM}$, inside which was a compressed-air pistol equipped with un upper cup used to spray the liquid onto the particles.

Table 1. Experimental design for the production of particleboard.

\begin{tabular}{|c|c|c|c|}
\hline Treatment & Species & Classification & $\begin{array}{c}\text { Adhesive } \\
\text { content (\%) }\end{array}$ \\
\hline $\mathrm{T} 1$ & \multirow{2}{*}{$\begin{array}{l}\text { Caryocar } \\
\text { villosum }\end{array}$} & With fines & \multirow{2}{*}{8} \\
\hline $\mathrm{T} 4$ & & Without fines & \\
\hline $\mathrm{T} 2$ & \multirow{2}{*}{$\begin{array}{c}\text { Tachigali } \\
\text { myrmecophyla }\end{array}$} & With fines & \multirow{2}{*}{8} \\
\hline T5 & & Without fines & \\
\hline T3 & \multirow{2}{*}{$\begin{array}{c}\text { Hymenolobium } \\
\text { excelsum }\end{array}$} & With fines & \multirow{2}{*}{8} \\
\hline T6 & & Without fines & \\
\hline
\end{tabular}

The particles already impregnated with adhesive and paraffin were manually placed into a mat-forming wooden box with dimensions of $400 \mathrm{~mm}$ for the inner edge and $200 \mathrm{~mm}$ height. After the particulate-mat underwent cold pre-pressing, it was placed in a hydraulic press for hot pressing. The maximum pressure used during the pressing of the panels was $35 \mathrm{kgf} / \mathrm{cm}^{2}$ at a temperature of $180^{\circ} \mathrm{C}$ and total time equal to 10 minutes using $15.7 \mathrm{~mm}$ thick separators.

After cooling, the particleboards were conditioned in an air-conditioned room with controlled temperature and relative humidity at $22 \pm 2{ }^{\circ} \mathrm{C}$ and $65 \pm 5 \%$, respectively, remaining there until achieving constant mass, indicating that they had reached equilibrium moisture in this environment.

From the physical-mechanical tests performed, the following particleboard properties were evaluated: specific mass, moisture content, water absorption after 2 and 24 hours of immersion, thickness swelling after 2 and 24 hours of immersion, modulus of rupture (MoR) and modulus of elasticity (MoE) to static bending, and resistance to perpendicular traction (internal bonding). Specimen dimensions, test realization and calculation of property values complied with the requirements of standard NBR 14810-3 (ABNT, 2006).

\subsection{Statistical analysis}

In order to verify the treatment effects on the properties of the particleboards produced, analyses of variance were performed, and Tukey average tests were subsequently conducted at the $5 \%$ probability in order to identify the means that differed from one another, using the SISVAR program. The mean values of each property evaluated were obtained per treatment and then compared with the minimum values specified by standard ANSI A208.1 (CPA, 2009) for high density particleboards (H-1 classification) and particleboards for floor underlaying (PBU classification).

\section{RESULTS AND DISCUSSION}

\subsection{Particle classification}

Mean values obtained by the particle size analysis in the different species are shown in Table 2.

In analyzing the results presented in Table 2, the predominance of particles retained between the 2.00 and $0.85 \mathrm{~mm}$ meshes is notable. Despite a $4 \mathrm{~mm}$ 
sieve being used in the knife mill during the particle production process, a small number of particles were retained in the $4.00 \mathrm{~mm}$ screen of the vibrating machine, possibly due to material handling during wood chip processing and the residues adhered to the sieve mesh. In any case, this fraction of the material was discarded prior to particleboard manufacturing.

The analyses of variance for particle distribution show a significant difference between the woods. It is noticeable that the Hymenolobium excelsum Ducke wood presented the smallest number of particles retained in $2.00 \mathrm{~mm}$ mesh sieves, and the greatest amount was retained in the $0.85 \mathrm{~mm}$ and $0.50 \mathrm{~mm}$ mesh sieves, differing from the Caryocar villosum (Aubl.) Pers. and Tachigali myrmecophyla Ducke woods (Table 2). All three species were statistically equivalent in terms of the presence of fines $(<0.50 \mathrm{~mm})$. Albuquerque \& Latorraca (2000) report that abrupt changes in density and high porosity of wood can generate more fines at the end of the particle production process. However, an anatomical characterization of the species was not realized in the present study and further research is necessary.

\subsection{Physical properties}

Mean values of the specific mass of each particleboard for each treatment are shown in Table 3.
Mean values of the specific mass of the particleboards varied between 819.01 to $845.93 \mathrm{~kg} \cdot \mathrm{m}^{-3}$ (Table 3), which characterizes them as high-density particleboards, since they presented values above $800 \mathrm{~kg} \cdot \mathrm{m}^{-3}$ according to what is established by standard ANSI A208.1 (CPA, 2009). According to the analysis of variance, no significant difference between treatments was observed, demonstrating that the production stage was well conducted. Despite no significant difference between treatments being observed, it is notable that after removing the fines, specific mass values for treatments $\mathrm{T} 4, \mathrm{~T} 5$ and $\mathrm{T} 6$ showed a tendency to increase, and were very close to the nominal specific mass intended for the panels (850 kg.m $\left.{ }^{-3}\right)$.

Mean thickness values for each treatment are presented in Table 4. According to analysis of variance, a significant difference was found between the treatments for the factors of classification and species. According to the same analysis of variance, a significant interaction was also found between the treatment factors.

The average particleboard thickness values (Table 4) ranged from 15.85 to $16.40 \mathrm{~mm}$. Considering that the separators used in the mat pressing step were $15.7 \mathrm{~mm}$ thick, it is noticeable that the treatments presented greater thickness values after removing the fines than those of the separator.

Table 2. Particle size analysis.

\begin{tabular}{cccccc}
\hline \multirow{2}{*}{ Species } & $\mathbf{4 . 0 0} \mathbf{~ m m}$ & $\mathbf{2 . 0 0} \mathbf{~} \mathbf{m}$ & $\mathbf{0 . 8 5} \mathbf{~} \mathbf{m}$ & $\mathbf{0 . 5 0} \mathbf{~} \mathbf{m m}$ & $<\mathbf{0 . 5 0} \mathbf{~} \mathbf{m}$ \\
\cline { 2 - 6 } & & $\mathbf{\%}$ & & \\
Caryocar villosum & $1.42 \mathrm{a}(0.08)$ & $37.80 \mathrm{~b}(1.79)$ & $47.73 \mathrm{a}(3.18)$ & $5.83 \mathrm{a}(0.63)$ & $7.21 \mathrm{a}(1.90)$ \\
Tachigali myrmecophyla & $1.82 \mathrm{a}(0.46)$ & $38.60 \mathrm{~b}(1.48)$ & $47.22 \mathrm{a}(1.12)$ & $5.42 \mathrm{a}(0.20)$ & $6.95 \mathrm{a}(0.92)$ \\
\hline Hymenolobium excelsum & $1.19 \mathrm{a}(0.03)$ & $26.63 \mathrm{a}(2.57)$ & $53.29 \mathrm{~b}(0.55)$ & $9.95 \mathrm{~b}(1.07)$ & $8.95 \mathrm{a}(1.43)$ \\
\hline
\end{tabular}

Means followed by the same letter do not differ statistically by Tukey test $(\alpha=0.05)$. Values in parenthesis represent the standard deviation.

Table 3. Mean values of apparent density of the panels for each treatment.

\begin{tabular}{|c|c|c|c|}
\hline \multirow{2}{*}{ Treatment } & \multirow{2}{*}{ Species } & \multirow{2}{*}{ Classification } & Apparent density \\
\hline & & & $\left(\mathrm{kg} \cdot \mathrm{m}^{-3}\right)$ \\
\hline $\mathrm{T} 1$ & Caryocar villosum & \multirow{3}{*}{ With fines } & $832.13 \mathrm{a}$ \\
\hline $\mathrm{T} 2$ & Tachigali myrmecophyla & & $828.16 \mathrm{a}$ \\
\hline T3 & Hymenolobium excelsum & & $819.01 \mathrm{a}$ \\
\hline $\mathrm{T} 4$ & Caryocar villosum & \multirow{3}{*}{ Without fines } & $845.93 \mathrm{a}$ \\
\hline T5 & Tachigali myrmecophyla & & $834.82 \mathrm{a}$ \\
\hline T6 & Hymenolobium excelsum & & $837.03 \mathrm{a}$ \\
\hline
\end{tabular}

Means followed by the same letter do not differ statistically by Tukey test $(\alpha=0.05)$. 
Regarding the particle classification factor, Table 4 shows that there was a significant difference for particleboards produced with Tachigali myrmecophyla Ducke and Hymenolobium excelsum Ducke particles. According to this Table, by analyzing the species factor we can verify that Caryocar villosum (Aubl.) Pers. particleboards without fines were significantly different from the others, presenting the lowest average thickness value.

By analyzing the interaction (Table 4), it can be observed that with the exception of particleboards produced with Caryocar villosum (Aubl.) Pers. wood, the others were significantly different, with the removal of fines promot an increase in panel thickness. Although this increase did not result in significant differences in the specific mass of the panels, it shows that they released compressive stresses post hot-pressing in greater magnitude, resulting in increased panel thickness after this process.

Mean moisture content values are shown in Table 5. The analysis of variance performed shows that there was a significant difference between treatments for the species factor, however no differences for the classification factor or significant interaction between the treatment factors were found.

The results shown in Table 5 indicate that Hymenolobium excelsum Ducke particleboards differed significantly from the others, presenting the lowest moisture content average value.

The average water absorption (AAw) values for the particleboards after two (AAw2h) and twenty-four hours of immersion (AAw24h) for each treatment are presented in Table 6. The analyses of variance performed for AAw2h and AAw24h indicate a significant difference between the treatments for the species and classification factors. According to the same analysis, a significant interaction was also found between these two factors.

According to the data in Table 6, by analyzing the classification factor, it can be observed that particleboards produced without fines showed a significant difference for all treatments when compared to panels produced with fines, indicating that the classification had a positive effect on this property and considering that the average values for $A A w 2 h$ and $A A w 24 h$ diminished. In analyzing the species, we can verify that the panels produced with Caryocar villosum (Aubl.) Pers. wood were significantly different from the others in both classifications, presenting the lowest AAw2h and AAw24h values.

According to an analysis of the interactions (Table 6), it was found that removing the fines from the different

Table 4. Mean values of thickness of the interaction between the factors classification and specie.

\begin{tabular}{|c|c|c|}
\hline \multirow{3}{*}{ Specie } & \multicolumn{2}{|c|}{ Classification } \\
\hline & With fines & Without fines \\
\hline & \multicolumn{2}{|c|}{ Thickness (mm) } \\
\hline $\begin{array}{l}\text { Caryocar } \\
\text { villosum }\end{array}$ & $15.85 \mathrm{aA}$ & $15.97 \mathrm{aA}$ \\
\hline $\begin{array}{c}\text { Tachigali } \\
\text { myrmecophyla }\end{array}$ & $15.93 \mathrm{aA}$ & $16.40 \mathrm{bB}$ \\
\hline $\begin{array}{l}\text { Hymenolobium } \\
\text { excelsum }\end{array}$ & $15.99 \mathrm{aA}$ & $16.31 \mathrm{bB}$ \\
\hline
\end{tabular}

Means followed by the same letter do not differ statistically by the Tukey test $(\alpha=0.05)$. Lowercase letters, in the lines, refer to values of the classification and uppercase letters, in the columns, values of the species.

Table 5. Mean values of moisture content of the specie factor.

\begin{tabular}{cc} 
Specie & Moisture content \\
\cline { 2 - 2 } & $\%$ \\
\hline Caryocar villosum & $9.4 \mathrm{~b}(0.21)$ \\
Tachigali myrmecophyla & $9.7 \mathrm{~b}(0.28)$ \\
\hline Hymenolobium excelsum & $8.6 \mathrm{a}(0.25)$ \\
\hline
\end{tabular}

Means followed by the same letter do not differ statistically by the Tukey test $(\alpha=0.05)$. Values in parenthesis represent the standard deviation.

Table 6. Mean values of water absorption of the interaction between the factors classification and specie.

\begin{tabular}{ccc}
\hline \multirow{2}{*}{ Specie } & \multicolumn{2}{c}{ Classification } \\
\cline { 2 - 3 } & \multicolumn{2}{c}{ AAw2h (\%) } \\
\cline { 2 - 3 } $\begin{array}{c}\text { Caryocar } \\
\text { villosum }\end{array}$ & $16.51 \mathrm{bA}$ & $10.55 \mathrm{aA}$ \\
$\begin{array}{c}\text { Tachigali } \\
\text { myrmecophyla }\end{array}$ & $37.80 \mathrm{bB}$ & $31.61 \mathrm{aC}$ \\
\hline $\begin{array}{c}\text { Hymenolobium } \\
\text { excelsum }\end{array}$ & $34.31 \mathrm{bB}$ & $19.29 \mathrm{aB}$ \\
\hline \multicolumn{2}{c}{ AAw24h (\%) } \\
\hline $\begin{array}{c}\text { Caryocar } \\
\text { villosum }\end{array}$ & $36.87 \mathrm{bA}$ & $27.64 \mathrm{aA}$ \\
\hline $\begin{array}{c}\text { Tachigali } \\
\text { myrmecophyla }\end{array}$ & $53.79 \mathrm{bC}$ & $44.71 \mathrm{aC}$ \\
\hline $\begin{array}{c}\text { Hymenolobium } \\
\text { excelsum }\end{array}$ & $50.27 \mathrm{bB}$ & $36.47 \mathrm{aB}$ \\
\hline
\end{tabular}

Means followed by the same letter do not differ statistically by the Tukey test $(\alpha=0.05)$. Lowercase letters, in the lines, refer to values of the classification and uppercase letters, in the columns, values of the species. 
species used for manufacturing the particleboards resulted in a statistically significant effect on the variables AAw2h and AAw24h, improving the results for this property. In evaluating the particle size of Pinus taeda wood particles for manufacturing particleboards, Peixoto \& Brito (2000) found that particles with a larger particle size have a smaller specific surface, and consequently a smaller area for water absorption.

The ANSI A208.1 standard (CPA, 2009) does not specify values for the physical property of water absorption; however, it can be inferred that the values found for the panels were compatible with data from the literature. In evaluating sawmill residues in the production of agglomerated wood panels from eucalyptus, Iwakiri et al. (2000) found AAw2h values between $13.94 \%$ and $41.74 \%$, and AAw24h values between $37.37 \%$ and $58.80 \%$. In panels produced with Amazonian species, Trianoski et al. (2015) found AAw2h values between $5.91 \%$ and $19.71 \%$, and AAw24h values between $20.65 \%$ and $32.98 \%$.

Mean swelling thickness values of the particleboards after two hours of immersion (ST2h) for classification and species factors are presented in Tables 7 and 8 , respectively. According to the analysis of variance, a significant difference was found between treatments for the factors, however no significant interaction was observed between them.

Considering the classification factor (Table 7), a significant difference was found between the particleboards, in which the removal of fines caused a positive effect on the property, reducing the ST2h value.

According to Table 8, particleboards made out of Caryocar villosum (Aubl.) Pers. particles were significantly different from the others, being the most efficient for ST2h, since they presented the lowest average value for this property.

Mean swelling thickness values for the particleboards after twenty-four hours immersion (ST24h) for each treatment are presented in Table 9. The analysis of variance performed for ST24h shows a significant difference for the factors evaluated and the interaction between both.

By analyzing the classification factor (Table 9), it can be observed that with the exception of particleboards produced with Caryocar villosum (Aubl.) Pers., the other species presented significant differences in relation to the removal of fines and showed higher
Table 7. Mean values of ST2h of the classification factor.

\begin{tabular}{cc} 
Classification & ST2h \\
\cline { 2 - 2 } & $\%$ \\
\hline With fines & $8.13 \mathrm{~b}(3.01)$ \\
\hline Without fines & $7.17 \mathrm{a}(3.77)$ \\
\hline
\end{tabular}

Means followed by the same letter do not differ statistically by the Tukey test $(\alpha=0.05)$. Values in parenthesis represent the standard deviation.

Table 8. Mean values of ST2h of the specie factor.

\begin{tabular}{cc} 
Specie & ST2h \\
\cline { 2 - 2 } Caryocar villosum & $\%$ \\
\hline Tachigali myrmecophyla & $4.10 \mathrm{a}(0.82)$ \\
\hline Hymenolobium excelsum & $7.70 \mathrm{c}(0.81)$ \\
\hline
\end{tabular}

Means followed by the same letter do not differ statistically by the Tukey test $(\alpha=0.05)$. Values in parenthesis represent the standard deviation.

Table 9. Mean values of ST24h of the interaction between the factors classification and specie.

\begin{tabular}{ccc}
\multirow{2}{*}{ Specie } & \multicolumn{2}{c}{ Classification } \\
\cline { 2 - 3 } & $\begin{array}{c}\text { With } \\
\text { fines }\end{array}$ & $\begin{array}{c}\text { Without } \\
\text { fines }\end{array}$ \\
\cline { 2 - 3 } Caryocar villosum & \multicolumn{2}{c}{ ST24h \% } \\
\hline Tachigali myrmecophyla & $10.80 \mathrm{aA}$ & $10.90 \mathrm{aA}$ \\
\hline Hymenolobium excelsum & $12.95 \mathrm{aC}$ & $17.62 \mathrm{bC}$ \\
\hline
\end{tabular}

Means followed by the same letter do not differ statistically by the Tukey test $(\alpha=0.05)$. Lowercase letters, in the lines, refer to values of the classification and uppercase letters, in the columns, values of the species.

ST24h values. By analyzing the species, we can verify significant differences in the TS24h values between the classifications in which treatments consisting of Caryocar villosum (Aubl.) Pers. had the lowest ST24h values in each of them.

According to the analysis of this interaction (Table 9), it can be highlighted that the combination of the species with removal of fines in manufacturing Tachigali myrmecophyla Ducke and Hymenolobium excelsum Ducke particleboards resulted in a statistically significant increase for the ST24h variable. The release of the compression stresses for both cases of post hot-press and post-immersion in water for 24 hours were of greater magnitude. Additionally, according to Albuquerque (2002), the use of finer particles in the composition of particleboards generally leads to better stability in the thickness, since the smaller mass 
of each particle in conjunction with the increase in the number of particle-particle interfaces allows for better dispersion of the hygroscopic swelling in the interparticle gaps. Considering the longer immersion time, it is assumed that the increase in swelling is partly inherent to the wood and is due to the adsorption of water by the hydroxyl groups, which are present in the chemical components of the cellulosic wall.

It can be stated that the ST2h and ST24h values for the manufactured particleboards are consistent and/or inferior when compared to data from the literature. Manufacturing particleboards with phenol-formaldehyde adhesive and larger-particles, Peixoto \& Brito (2000) found values ranging from 6.04 to $15.20 \%$ and 9.56 to $16.95 \%$ for ST2h and ST24h, respectively. Brito \& Silva (2002) manufactured Gmelina arborea and Samanea saman particleboards with different particle sizes and found values ranging from 6.88 and $17.86 \%$ for ST2h and from 17.41 and $24.92 \%$ for ST24h. The authors concluded that panels produced with smaller particles presented smaller swelling thickness.

The ANSI A208.1 standard (CPA, 2009) does not specify values for the swelling thickness property for $\mathrm{H}-1$ and PBU classifications. Therefore, the values found were compared with those for D-2 classification (panels used in decks), which stipulates a maximum value of $8 \%$ swelling thickness after twenty-four hours immersion in water. According to data from Table 9, it is noticeable that particleboards from all treatments presented higher average values than indicated by the norm in the reference, thereby presenting non-compliance. However, particleboards produced with Caryocar villosum (Aubl.) Pers. presented values close to requirements.

\subsection{Mechanical properties}

The mean values found for the modulus of rupture (MoR) and modulus of elasticity (MoE) of the particleboards to static bending considering classification and species factors are presented in Tables 10 and 11, respectively. According to the analyses of variance, a significant difference between the treatments for both factors was found, however no significant interaction between them was observed.

Considering the classification factor (Table 10), we can affirm that the removal of fines was efficient, given that the mean values for panels without fines
Table 10. Means values of MoR and MoE of the classification factor.

\begin{tabular}{cccc} 
Classification & $\mathbf{M o R}$ & & $\mathbf{M o E}$ \\
\cline { 2 - 3 } & $\mathbf{M P a}$ & & $\mathbf{M P a}$ \\
\hline With fines & $9.27 \mathrm{a}(1.19)$ & & $1376.85 \mathrm{a}(258.58)$ \\
Without fines & $13.80 \mathrm{~b}(2.48)$ & & $1846.65 \mathrm{~b}(183.24)$ \\
\hline
\end{tabular}

Means followed by the same letter do not differ statistically by the Tukey test $(\alpha=0.05)$. Values in parenthesis represent the standard deviation.

Table 11. Mean values of MoR and MoE of the specie factor.

\begin{tabular}{cccc}
\multirow{2}{*}{ Specie } & MoR & & MoE \\
\cline { 2 - 2 } $\begin{array}{c}\text { Caryocar } \\
\text { villosum }\end{array}$ & MPa & & MPa \\
$\begin{array}{c}\text { Tachigali } \\
\text { myrmecophyla }\end{array}$ & $13.27 \mathrm{~b}(1.72)$ & & $1796.18 \mathrm{a}(258.87)$ \\
$\begin{array}{c}\text { Hymenolobium } \\
\text { excelsum }\end{array}$ & $10.99 \mathrm{a}(3.01)$ & & $1604.13 \mathrm{ab}(362.78)$ \\
\hline
\end{tabular}

Means followed by the same letter do not differ statistically by the Tukey test $(\alpha=0.05)$. Values in parenthesis represent the standard deviation.

differed significantly from panels with fines, and showed better performances for MoR and MoE. This effect is a result of altering the specific surface area, the relative adhesive consumption and the contact area between the particles. Considering panels with the same dimensions, the same specific mass and application of the same adhesive content, using larger particles will result in reducing their specific surface area, and increasing the adhesive availability per unit of surface area of the particles, which can result in panels with improved properties (Moslemi, 1974; Maloney, 1993).

Nemli et al. (2007) used particles that went through a $0.25 \mathrm{~mm}$ sieve at different mixing ratios to manufacture particleboards, observing a decreasing tendency for the MoR and MoE values obtained with an increase in the proportion of fine particles. In evaluating the influence of particle dimensions on particleboard properties, Lias et al. (2014) found that increasing particle size from $1.0 \mathrm{~mm}$ to $2.0 \mathrm{~mm}$ also increased MoR and MoE values.

For MoR, the ANSI A208.1 standard (CPA, 2009) indicates minimum values of 14.9 and $11 \mathrm{MPa}$ for the $\mathrm{H}-1$ and PBU classifications, respectively. Given the above, the result of the modulus of rupture to static flexion of the particleboards produced without fines was higher than that stipulated by the standard for the PBU 
classification (Table 10). For MoE, the same standard stipulates a minimum value of 2160 and $1725 \mathrm{MPa}$ for the $\mathrm{H}-1$ and $\mathrm{PBU}$ classifications, respectively. Analyzing the data in Table 10, it can be observed that particleboards without fines met the standard in question for the PBU classification.

According to the data in Table 11, the mean MoR value for particleboards made of Tachigali myrmecophyla Ducke wood were higher and significantly different from the particleboards containing Caryocar villosum (Aubl.) Pers. and Hymenolobium excelsum Ducke woods in their composition. In turn, these showed statistically equivalent mean values.

Regarding MoE, according to the data in Table 11, it can be verified that Caryocar villosum (Aubl.) Pers. particleboards were statistically equivalent to Tachigali myrmecophyla Ducke particleboards, and different from those made with Hymenolobium excelsum Ducke, presenting the highest value. Particleboards produced with Caryocar villosum (Aubl.) Pers. wood also presented the highest values of specific mass, however with no statistically significant difference in relation to the others, indicating that there may have been influence from this variable on the result.

The mean internal bond values of the particleboards for the classification and species factors are shown in Tables 12 and 13, respectively. According to the analyses of variance, a significant difference was found between the treatments for these factors, however no significant interaction between them was observed.

Considering the classification factor (Table 12), a significant difference was found between the particleboards in which the removal of fines resulted in a positive effect on this property, increasing the internal bond value. When applying the same amount of adhesive, particleboards produced with larger particles have greater internal bonding due to the smaller specific surface area, and consequently a greater availability of adhesive per unit area (Maloney, 1993). According to Jagger (1992), a higher percentage of fines increases the consumption of adhesive, thus impairing the particleboard quality and reducing the internal adhesion.

When analyzing the influence of adding sawdust on the technological properties of wood panels, Torrell et al. (2013) found internal bond values ranging from 0.15 to $0.52 \mathrm{MPa}$, and also found that an increase in
Table 12. Mean values of internal bond of the classification factor.

\begin{tabular}{cc} 
Classification & Internal bond \\
\cline { 2 - 2 } & $\mathbf{M P a}$ \\
\hline With fines & $1.16 \mathrm{a}(0.27)$ \\
Without fines & $1.61 \mathrm{~b}(0.32)$ \\
\hline
\end{tabular}

Means followed by the same letter do not differ statistically by the Tukey test $(\alpha=0.05)$. Values in parenthesis represent the standard deviation.

Table 13. Mean values of internal bond of the specie factor.

\begin{tabular}{cc|} 
Specie & Internal bond \\
\cline { 2 - 2 } & $\mathbf{M P a}$ \\
\hline Caryocar villosum & $1.05 \mathrm{a}(0.22)$ \\
\hline Tachigali myrmecophyla & $1.50 \mathrm{~b}(0.36)$ \\
\hline Hymenolobium excelsum & $1.59 \mathrm{~b}(0.29)$ \\
\hline
\end{tabular}

Means followed by the same letter do not differ statistically by the Tukey test $(\alpha=0.05)$. Values in parenthesis represent the standard deviation.

sawdust proportion caused a decrease in internal binding values. Vital et al. (1992) manufactured particleboards using two particle thicknesses $(0.39$ and $0.74 \mathrm{~mm})$ and found that the resistance to internal bonding was greater in panels produced with thicker particles.

The ANSI A208.1 standard (CPA, 2009) indicates a minimum value for the internal bonding property equal to $0.81 \mathrm{MPa}$ for the $\mathrm{H}-1$ classification and 0.40 for the PBU classification. Based on the data in Table 12, it is possible to verify that the particleboards exhibited average internal bond values above the minimum required by this norm for both classifications.

According to Table 13, Caryocar villosum (Aubl.) Pers. particleboards differed significantly from the other species and had the least efficient internal bond presenting the lowest average value for this property.

\section{CONCLUSION}

Removing fines from the manufactured particleboards resulted in a tendency of increasing values for their mechanical properties (MoR, MoE and internal bond). This variable also contributed to reducing AAw2h, AAw24h and ST2h. However, it also influenced ST24h, where the values showed a tendency to increase. The particleboards produced with residues without fines presented the greatest potential for use, since 
they met the minimum requirements indicated by the ANSI A208.1 standard (CPA, 2009) for all mechanical properties evaluated.

\section{ACKNOWLEDGEMENTS}

We would like to thank the International Tropical Timber Organization (ITTO), the National Hardwood Flooring Association Brazil (ANPM), the Coordination for the Improvement of Higher Education Personnel (CAPES) and the Lamination and Wood Panels Laboratory (LLAPAM) of Department of Forest Sciences (LCF) of ESALQ/USP, for the support in the development of the research.

\section{SUBMISSION STATUS}

Received: 31 july, 2017

Accepted: 31 aug., 2017

\section{CORRESPONDENCE TO}

\section{Paula Gabriella Surdi}

Departamento de Ciências Florestais, Escola Superior de Agricultura "Luiz de Queiroz" ESALQ, Universidade de São Paulo - USP, Av. Pádua Dias, 11, CEP 13418-900, Piracicaba, SP, Brasil

e-mail: paulasurdi@gmail.com

\section{REFERENCES}

Albuquerque CEC, Latorraca JVF. Influência das características anatômicas da madeira na penetração e adesão de adesivos. Floresta e Ambiente 2000; 7(1): 158-166.

Albuquerque CEC. Interações de variáveis no ciclo de prensagem de aglomerados [tese]. Curitiba: Setor de Ciências Florestais, Universidade Federal do Paraná; 2002.

Associação Brasileira de Normas Técnicas - ABNT. NBR 14810-3: chapas de madeira aglomerada: métodos de ensaio. Rio de Janeiro: ABNT; 2006.

Brito EO, Silva VC. Propriedade de chapas de partículas produzidas a partir de Gmelina arborea Linn. Roxb. e Samanea saman (Jacq.) Merr. Floresta e Ambiente 2002; 9(1): 127-134.

Brito EO. Produção de chapas de partículas de madeira a partir de maravalhas de Pinus elliotti Engelm. Var. elliotti plantado no sul do Brasil [tese]. Curitiba: Setor de Ciências Florestais, Universidade Federal do Paraná; 1995.
Composite Panel Association - CPA. ANSI A 208.1: particleboard standard. Leesburg: CPA; 2009.

Frybort S, Mauritz R, Teischinger A, Muller U. Cement bonded composites: a mechanical review. Bioresource Technology 2008; 3(2): 602-626.

Iwakiri S, Cunha AB, Albuquerque CEC, Gorniak E, Mendes LM. Resíduos de serrarias na produção de painéis de madeira aglomerada de eucalipto. Scientia Agraria 2000; 1(1): 23-28. http://dx.doi.org/10.5380/rsa.vli1.963.

Iwakiri S. A influência de variáveis de processamento sobre propriedades de chapas de partículas de diferentes espécies de Pinus [tese]. Curitiba: Setor de Ciências Florestais, Universidade Federal do Paraná; 1989.

Iwakiri S. Painéis de madeira reconstituída. Curitiba: FUPEF; 2005.

Jagger RW. The new pallmann ring refiner, type PF, for green sawdust, shavings, and other such materials. In: Proceedings of the 26th International Particleboard Composite Materials Symposium; 1992; Pullman. Pullman: Washington State University; 1992. p. 94-105.

Juliana AH, Paridah MT, Rahim S, Nor Azowa I, Anwar UMK. Properties of particleboard made from kenaf (Hibiscus cannabinus L.) as function of particle geometry. Materials \& Design 2012; 34: 406-411. http://dx.doi. org/10.1016/j.matdes.2011.08.019.

Lias H, Kasim J, Johari NAN, Mokhtar ILM. Influence of board density and particle sizes on the homogenous particleboard properties from kelempayan (Neolamarckia cadamba). International Journal of Latest Research in Science and Technology 2014; 3(6): 173-176.

Maloney TM. Modern particleboard e dry-process fiberboard manufacturing. 2nd ed. San Francisco: Miller Freeman; 1993.

Moslemi AA. Particleboard: technology. London: Southern Illinois University; 1974.

Nemli G, Aydin I, Zekovic E. Evaluation of some of the properties of particleboard as function of manufacturing parameters. Materials \& Design 2007; 28(4): 1169-1176. http://dx.doi.org/10.1016/j.matdes.2006.01.015.

Ong CL. The influence of wood density and flake dimensions on particleboard properties of five hardwood species. Malaysian Forester 1981; 44(4): 508-515.

Peixoto GL, Brito EO. Avaliação da granulometria de partículas de Pinus taeda combinadas com adesivos comerciais para a fabricação de aglomerados. Floresta $e$ Ambiente 2000; 7(1): 60-67.

Rackwitz G. Influence of chip dimensions on some properties of wood particleboard. European Journal of Wood and Wood Products 1963; 21(6): 200-209. http:// dx.doi.org/10.1007/BF02609724.

Rofii MN, Yumigeta S, Kojima Y, Suzuki S. Effect of furnish type and high-density raw material from mill residues on properties of particleboard panels. Journal of Wood 
Science 2013; 59(5): 402-409. http://dx.doi.org/10.1007/ s10086-013-1353-3.

Stark NM, Cai Z, Carll C. Wood-based composite materials: panel products, glued-laminated timber, structural composite lumber, and wood: nonwood composite materials. In: Ross RJ, editor. Wood handbook: wood as an engineering material. Wisconsin: USDA, Forest Service, Forest Products Laboratory; 2010. chap. 11, p. 1-28.

Torrell R, Hillig E, Corradi GM, Iwakiri S. Influência da adição de serragem nas propriedades tecnológicas de painéis de madeira aglomerada de Pinus taeda.
Ambiência 2013; 9(1): 57-72. http://dx.doi.org/10.5777/ ambiencia.2013.01.04.

Trianoski R, Iwakiri S, Nascimento CC. BILA NF. Painéis aglomerados produzidos com quatro espécies de madeiras tropicais da Amazônia. Scientia Forestalis 2015; 43(106): 445-452.

Vital BR, Haselein CR, Della Lucia RM. Efeito da geometria das partículas nas propriedades das chapas de madeira aglomerada de Eucalyptus grandis (Hill ex-Maiden). Revista Árvore 1992; 16(1): 88-96. 